\title{
Milk yield, milk composition, and hepatic lipid metabolism in transition dairy cows fed flaxseed or linola
}

\author{
R. M. do Prado, ${ }^{*}$ M. F. Palin, $\dagger$ I. N. do Prado, ${ }^{*}$ G. T. dos Santos, ${ }^{*}$ C. Benchaar, $\dagger$ and H. V. Petit ${ }^{1}$ \\ *Departamento de Zootecnia, Universidade Estadual de Maringa, 87020-090 Maringa, PR, Brazil \\ †Sherbrooke Dairy and Swine Research and Development Centre, Agriculture and Agri-Food Canada, Sherbrooke, QC J1M 0C8, Canada
}

\begin{abstract}
The response of transition dairy cows to dietary supplementation with fat sources of various fatty acid profiles could affect hepatic fat metabolism differently. Twenty-eight Holstein cows were blocked for similar calving date $4 \mathrm{wk}$ before expected parturition to compare the effects of feeding sources of n-3 and n- 6 fatty acids on milk production and composition, plasma metabolites, and liver parameters. Cows within each block were assigned to 1 of 3 isonitrogenous and isoenergetic diets: control with a source of calcium salts of palm oil (MEG; 1.1 and $2.6 \%$ of the dry matter in prepartum and postpartum diets, respectively); n-3 fatty acids supplied as whole flaxseed (WFL; 4.8 and $7.7 \%$ of the dry matter in prepartum and postpartum diets, respectively); and n-6 fatty acids supplied as whole linola (WLO; 4.8 and $7.7 \%$ of the dry matter in prepartum and postpartum diets, respectively). Diets were fed until wk 14 of lactation. Contrasts of WFL versus WLO and polyunsaturated fatty acids versus MEG were compared. Cows fed polyunsaturated fatty acids increased dry matter intake over time at a greater extent than those fed MEG, which resulted in enhanced energy balance. Cows fed MEG produced more milk compared with those fed polyunsaturated fatty acids, and there was no difference between those fed WFL and WLO. We found no effect on body condition score and body weight. Plasma concentrations of glucose, fatty acids, and BHB were similar among diets. There was no effect of diet on concentration of glycogen and activities of superoxide dismutase and glutathione peroxidase in the liver. We observed higher concentrations of hepatic lipids and triacylglycerol in cows fed MEG compared with those fed polyunsaturated fatty acids, and no difference between WFL and WLO. Hepatic catalase activity tended to be higher on wk 4 after calving for cows supplemented with WFL compared with
\end{abstract}

Received February 8, 2016 .

Accepted July 28, 2016.

${ }^{1}$ Corresponding author: helene.petit@agr.gc.ca those fed WLO. Feeding linoleic and linolenic acids as unprotected oilseeds increased dry matter intake over time at a greater extent for cows fed MEG, improved the energy status, and lowered hepatic lipids and triacylglycerol contents, which may contribute to enhance the health status of transition dairy cows.

Key words: dairy cow, fatty acids, fatty liver, flaxseed, linola

\section{INTRODUCTION}

Addition of lipids contributes to increase dietary energy density during the periparturient period (Grummer, 2008), but evidence exists that it increases plasma nonesterified fatty acid concentrations (Grummer and Carroll, 1991) that, in turn, could increase hepatic triacylglycerol (Grummer, 1993). However, an association between fatty acid composition of the lipid source and hepatic lipid metabolism has not been conclusive in dairy cattle (Mashek et al., 2002, 2005). Length of the supplementation period (i.e., initiated before or after calving or for the whole transition period) with fat sources also may influence the effect of supplementation on hepatic metabolism. For example, feeding up to $15 \%$ whole flaxseed, a rich source of n-3 fatty acids, from calving until wk 24 of lactation had no effect on plasma nonesterified fatty acid concentrations of dairy cows (Petit, 2015). Conversely, feeding whole flaxseed from 6 wk before calving increases concentrations of hepatic glycogen and decreases those of triacylglycerol in postpartum multiparous cows (Petit et al., 2007). Similarly, beneficial effects of feeding another rich source of n-3 fatty acids, such as fish oil or a saturated fat, during the transition period have been observed (Ballou et al., 2009).

Fatty acids play key roles on gene expression linked to fat metabolism (White et al., 2011). Flax hulls, a rich source of n-3 fatty acids, increase the mRNA abundance of various genes involved in fat metabolism of the dairy cow mammary gland (Palin et al., 2014). Flax products are also rich in antioxidants present as plant lignans (Adlercreutz and Mazur, 1997). Sesamin 
lignans increase the expression of genes involved in hepatic $\beta$-oxidation of rodents (Kiso, 2004) and flaxseed enhances antioxidant activity of hepatic enzymes such as superoxide dismutase (SOD), catalase (CAT), and peroxidase (Rajesha et al., 2006). More recently, Côrtes et al. (2012) observed that flax hulls increase SOD activity and SOD1 mRNA abundance in the mammary tissue of dairy cows, and Schogor et al. (2013) observed that flaxseed meal decreases thiobarbituric acid reactive substances production in ruminal fluid and increases mRNA abundance of the nuclear factor erythroid 2-like 2 (NFE2L2/Nrf2) in mammary tissue of dairy cows. Therefore, the effects of enhanced $\beta$-oxidation and increased hepatic, rumen, and mammary antioxidant capacity may contribute to prevent the fatty liver syndrome in dairy cows fed flax products.

Linola, a new cultivar of flax registered for production in Canada since 1999, contains approximately $70 \%$ C18:2 in the oil (Dribnenki et al., 1999), whereas flaxseed contains approximately $60 \% \mathrm{C} 18: 3$. The main difference between both oilseeds lies in the inverse proportions of linolenic and linoleic acids. Hayirli et al. (2011) have compared the effect of prepartum diets containing linola and flaxseed on hepatic lipidosis after calving and reported negligible effects on peripartum responses. However, no comparison exists between linola and flaxseed fed during the whole transition. Our hypotheses were that flaxseed improves performance of dairy cows compared with linola and that PUFA result in better performance than calcium salts of palm oil. Therefore, the primary objective of the present experiment was to compare the effects of feeding whole flaxseed and whole linola on concentrations of triacylglycerol, glycogen, total lipids, and antioxidant enzymes in the liver, and concentrations of fatty acids, BHB, and glucose in plasma of dairy cows from wk 4 before calving until wk 14 after calving. A secondary objective was to compare PUFA to calcium salts of palm oil, which are commonly used in the diet of dairy cows.

\section{MATERIALS AND METHODS}

\section{Animals and Treatments}

The experiment was conducted at the Dairy and Swine Research and Development Centre (QC, Canada) using 28 multiparous Holstein dry cows averaging (mean $\pm \mathrm{SE}$ ) $777 \pm 18 \mathrm{~kg}$ of BW and in parity $2.4 \pm$ 0.3. Two cows were removed from the data set as 1 cow aborted of twins and 1 experienced severe ketosis. The experiment was carried out from wk 4 before parturition up to wk 14 of lactation. Cows were blocked by trios for similar expected calving dates $4 \mathrm{wk}$ before calving.
Cows within blocks were assigned randomly to 1 of 3 isonitrogenous and isoenergetic TMR. The 3 prepartum TMR (Table 1) contained different fat sources (DM basis): unsaturated lipids supplied as $4.8 \%$ whole flaxseed (WFL, $\mathrm{n}=9$ ) rich in $\mathrm{n}-3$ fatty acids; unsaturated lipids supplied as $4.8 \%$ whole linola $(\mathbf{W L O}, \mathrm{n}=9$ ) rich in $\mathrm{n}-6$ fatty acids; or calcium salts of palm oil supplied as $1.1 \%$ Megalac (MEG, $\mathrm{n}=10$; Church and Dwight Co. Inc., Princeton, NJ). After calving, 3 TMR (Table 2) were formulated to meet requirements for cows that produced $40 \mathrm{~kg} / \mathrm{d}$ of milk with $3.90 \%$ fat (NRC, 2001). On a DM basis, postpartum diets WFL and WLO contained $7.7 \%$ whole flaxseed and $7.7 \%$ whole linola, respectively, and MEG contained 2.6\% Megalac. The amount of Megalac added to the postpartum diet was close to the 1 to $2 \%$ recommended by the manufacturer, whereas higher amounts of oilseeds were added to the diets as they have been shown to have no negative effects on DMI of cows when fed at up to $10 \%$ of the diet (e.g., Petit, 2010). Cows were fed individually twice a day at 0800 and $1500 \mathrm{~h}$ for $10 \%$ refusals for the whole experiment and feed consumption was recorded daily. Cows were housed in tiestalls and milked twice a day at 0730 and $1900 \mathrm{~h}$. Milk production was recorded at every milking. Cows were cared for in accordance with the guidelines of the Canadian Council on Animal Care (CCAC, 1993).

\section{Sampling}

Milk samples were obtained from each cow on wk $1,2,3,4,6,10$, and 12 for 2 consecutive milkings and pooled on a yield basis. Milk samples were stored at $4^{\circ} \mathrm{C}$ with a preservative (bronopol-B2) and analyzed for concentrations of protein, fat, and lactose and SCC. Milk samples without preservative were frozen at $-20^{\circ} \mathrm{C}$ until analyzed for milk fatty acids profile. Body weight and BCS of cows were determined on wk 4 and 1 prepartum, at calving, and on wk $1,2,3,4,8$, and 12 postpartum. Body condition score was determined on a scale of 1 to 5 (Edmonson et al., 1989). Silage DM was analyzed weekly for DM adjustment of the TMR. Samples of TMR, linola, and flaxseed were taken weekly, frozen, and composited on a 4 -wk basis for the prepartum period and a 6 -wk basis for the postpartum period. Composited samples were mixed thoroughly and subsampled for chemical analysis. Diets and feed ingredients were dried at $55^{\circ} \mathrm{C}$ and ground through a 1-mm sieve in a Wiley mill (standard model 4, Arthur M. Thomas, Philadelphia, PA) before analysis of $\mathrm{N}$, ether extract, NDF, and ADF. Postpartum energy balance was calculated weekly as the difference between energy consumed and required, where $\mathrm{NE}_{\mathrm{L}}$ required 
Table 1. Ingredient, chemical composition, and fatty acid profile of the precalving TMR containing a source of n-3 fatty acids supplied as whole flaxseed (WFL), n-6 fatty acids supplied as whole linola (WLO), or calcium salts of palm oil $\left(\mathrm{MEG}^{1}\right)$

\begin{tabular}{|c|c|c|c|c|}
\hline Item & WFL & WLO & MEG & SE \\
\hline \multicolumn{5}{|l|}{ Ingredient (\% of DM) } \\
\hline Corn silage & 26.5 & 26.5 & 26.4 & \\
\hline Chopped hay & 51.8 & 51.8 & 50.9 & \\
\hline Cracked corn grain & 1.9 & 1.9 & 5.2 & \\
\hline Soybean meal $(48 \% \mathrm{CP})$ & 12.8 & 12.8 & 14.4 & \\
\hline Calcium carbonate $(34 \%$ Ca) & 0.9 & 0.9 & 0.7 & \\
\hline Whole linola & 0 & 4.8 & 0 & \\
\hline Whole flaxseed & 4.8 & 0 & 0 & \\
\hline Megalac Low & 0 & 0 & 1.1 & \\
\hline Mineral and vitamin premix ${ }^{2}$ & 1.3 & 1.3 & 1.3 & \\
\hline \multicolumn{5}{|l|}{ Chemical analysis $^{3}$} \\
\hline $\mathrm{DM}(\%)$ & 44.9 & 44.6 & 45.4 & 0.5 \\
\hline $\mathrm{CP}(\%$ of $\mathrm{DM})$ & 19.6 & 20.6 & 20.1 & 0.9 \\
\hline Ether extract $(\%$ of $\mathrm{DM})$ & $6.2^{\mathrm{a}}$ & $6.5^{\mathrm{a}}$ & $3.1^{\mathrm{b}}$ & 0.2 \\
\hline $\mathrm{NDF}(\%$ of DM) & 24.5 & 24.1 & 22.4 & 0.8 \\
\hline $\mathrm{ADF}(\%$ of $\mathrm{DM})$ & 14.2 & 13.6 & 12.2 & 0.7 \\
\hline $\mathrm{NFC}^{4}(\%$ of $\mathrm{DM})$ & 42.6 & 41.7 & 47.6 & \\
\hline $\mathrm{NE}_{\mathrm{L}}^{4}(\mathrm{MJ} / \mathrm{kg})$ & 6.69 & 6.69 & 6.61 & \\
\hline \multicolumn{5}{|l|}{ Fatty acids (\% of total) } \\
\hline $14: 0$ & 0.13 & 0.12 & 0.68 & \\
\hline $16: 0$ & 9.32 & 9.30 & 28.50 & \\
\hline cis-9 16:1 & 0.14 & 0.12 & 0.23 & \\
\hline 18:0 & 3.28 & 3.29 & 3.42 & \\
\hline cis-9 18:1 & 19.88 & 18.74 & 26.86 & \\
\hline cis-11 18:1 & 0.78 & 0.74 & 0.90 & \\
\hline cis-9,cis-12 18:2 & 34.79 & 56.42 & 35.43 & \\
\hline cis-9,cis-12,cis-15 18:3 & 31.39 & 10.99 & 3.56 & \\
\hline $20: 0$ & 0.29 & 0.28 & 0.42 & \\
\hline
\end{tabular}

${ }_{\mathrm{a}, \mathrm{b}}$ Means within row with different superscripts differ $(P<0.05)$.

${ }^{1}$ Megalac, Church and Dwight Co. Inc., Princeton, NJ.

${ }^{2}$ Contained $6.27 \% \mathrm{Ca} ; 6.0 \% \mathrm{P} ; 20.0 \% \mathrm{Mg} ; 1.5 \% \mathrm{~S} ; 5.6 \% \mathrm{Na} ; 1.26 \% \mathrm{~K} ; 198 \mathrm{mg} / \mathrm{kg}$ of I; $2,846 \mathrm{mg} / \mathrm{kg}$ of Fe; 1,560 $\mathrm{mg} / \mathrm{kg}$ of $\mathrm{Cu} ; 6,698 \mathrm{mg} / \mathrm{kg}$ of Mn; 7,300 mg/kg of Zn; $128 \mathrm{mg} / \mathrm{kg}$ of Co; $332 \mathrm{mg} / \mathrm{kg}$ of F; 1,080,287 UI/ $\mathrm{kg}$ of vitamin $\mathrm{A} ; 189,951 \mathrm{UI} / \mathrm{kg}$ of vitamin $\mathrm{D}$; and 12,644 $\mathrm{UI} / \mathrm{kg}$ of vitamin $\mathrm{E}$.

${ }^{3}$ Mean of 4 weekly samples prepared by compositing weekly samples.

${ }^{4}$ Calculated using published values (NRC, 2001).

postpartum is $\mathrm{NE}_{\mathrm{L}}$ for maintenance plus $\mathrm{NE}_{\mathrm{L}}$ for milk. Energy required for maintenance was estimated as $(\mathrm{MJ} / \mathrm{d})=0.08 \times \mathrm{kg}$ of metabolic $\mathrm{BW}\left(\mathrm{BW}^{0.75}\right) \times$ 4.184; and energy for lactation as $(\mathrm{MJ} / \mathrm{d})=\mathrm{kg}$ of milk $\times[(0.0929 \times$ milk fat \% $)+(0.0547 \times$ milk protein $\%)$ $+0.192] \times 4.184(\mathrm{NRC}, 2001)$.

Blood was sampled on wk 2 and 1 prepartum, at calving, and on wk 1, 2, 4, 6 , and 8 postpartum. Mean actual weeks of blood sampling were the same as target weeks, with standard deviations ranging from 2.6 to $2.8 \mathrm{~d}$ for the prepartum period and 1.0 to $1.4 \mathrm{~d}$ for the postpartum period. Blood was collected after feed refusals were removed and before the morning feeding as described by Janovick et al. (2011). Blood was withdrawn from the coccygeal vein into vacutainer tubes (Becton, Dickinson and Co., Rutherford, NJ) containing EDTA for fatty acids, glucose, and BHB analysis. Tubes were immediately placed on ice and centrifuged within 30 min at $3,000 \times g$ for $12 \mathrm{~min}$ and at $4^{\circ} \mathrm{C}$. Plasma was separated and frozen at $-20^{\circ} \mathrm{C}$ for subsequent analy- sis. Samples of liver were collected from each cow on wk 2 prepartum and on wk 2 and 4 postpartum. Liver samples were obtained by puncture biopsy under local anesthesia through an incision on the right side of the cow at the 10th intercostal, where it crossed a line from mid-humerus to tuber coxae. An incision of approximately $1 \mathrm{~cm}$ long was made and about $2.5 \mathrm{~g}$ of liver tissue were collected at each biopsy. Upon collection, the liver samples were rinsed with saline to remove excess blood and immediately placed into liquid N. Samples were stored at $-80^{\circ} \mathrm{C}$ until analyzed for triacylglycerol, total lipids, and glycogen and antioxidant enzymes.

\section{Chemical Analysis}

Dry matter of TMR was determined in a forced-air oven at $105^{\circ} \mathrm{C}$ for $48 \mathrm{~h}$ (AOAC, 1990; method 934.01). Nitrogen and ether extract determinations in TMR and feed ingredients were determined according to method 990.03 and 920.39 of AOAC (1990), respectively. The 
concentration of NDF in TMR was determined with sodium sulfite and heat-stable $\alpha$-amylase (Van Soest et al., 1991), and the ADF content was determined according to AOAC (1990; method 973.18). The procedures for NDF and ADF analysis were adapted for use in an Ankom ${ }^{200}$ Fiber Analyzer (Ankom Technology Corp., Fairport, NY).

Nitrogen, fat, and lactose concentrations and SCC in milk were determined with a Foss MilkoScan4000 instrument (Foss Electric, Hillerød, Denmark) combined with a Bentley 2000 instrument (Bentley Instruments, Chaska, MN). Milk composition analysis was conducted at the Québec Dairy Production Centre of Expertise (Ste-Anne-de-Bellevue, QC, Canada). Total lipids in milk were extracted as described by Côrtes et al. (2010). Fatty acids were methylated according to the method described by Chouinard et al. (1997). Transesterification was performed on flaxseed, linola, and TMR according to Park and Goins (1994). Determination of the fatty acid profile was carried out by gasliquid chromatography on a chromatograph (HP 5890A Series II; Hewlett-Packard, Palo Alto, CA) equipped with a $100-\mathrm{m}$ CP-Sil 88 capillary column $(0.25 \mu \mathrm{m}$ i.d., $0.20 \mu \mathrm{m}$ film thickness; Chrompack, Middleburg, the Netherlands) and a flame ionization detector. The temperature program was as follows: level $1,80^{\circ} \mathrm{C}$ held for 1 min; level 2,80 to $215^{\circ} \mathrm{C}$ at a $2^{\circ} \mathrm{C} / \mathrm{min}$ increment, then held for $30 \mathrm{~min}$. Inlet and detector temperatures were 220 and $230^{\circ} \mathrm{C}$, respectively. The split ratio was 100:1. The flow rate for helium (carrier gas) was $1 \mathrm{~mL} / \mathrm{min}$. Most fatty acids peaks were identified and quantified using either a quantitative mixture or pure methyl ester

Table 2. Ingredient, chemical composition, and fatty acid profile of the postcalving TMR containing a source of n-3 fatty acids supplied as whole flaxseed (WFL), n-6 fatty acids supplied as whole linola (WLO), or calcium salts of palm oil $\left(\mathrm{MEG}^{1}\right)$

\begin{tabular}{|c|c|c|c|c|}
\hline Item & WFL & WLO & MEG & SE \\
\hline \multicolumn{5}{|l|}{ Ingredient $(\%$ of $\mathrm{DM})$} \\
\hline Grass silage & 28.7 & 28.7 & 28.6 & \\
\hline Corn silage & 28.7 & 28.7 & 28.6 & \\
\hline Cracked corn grain & 2.4 & 2.4 & 19.7 & \\
\hline Soybean meal ( $48 \%$ CP) & 5.2 & 5.2 & 13.3 & \\
\hline Beet pulp & 4.1 & 4.1 & 3.3 & \\
\hline Calcium carbonate $(34 \% \mathrm{Ca})$ & 0.7 & 0.7 & 0.2 & \\
\hline Corn gluten meal & 7.9 & 7.9 & 0 & \\
\hline Whole wheat & 11.1 & 11.1 & 0 & \\
\hline Whole linola & 0 & 7.7 & 0 & \\
\hline Whole flaxseed & 7.7 & 0 & 0 & \\
\hline Megalac Low & 0 & 0 & 2.6 & \\
\hline Protein supplement $^{2}$ & 2.0 & 2.0 & 1.8 & \\
\hline Mineral and vitamin premix ${ }^{3}$ & 1.5 & 1.5 & 1.9 & \\
\hline \multicolumn{5}{|l|}{ Chemical analysis $^{4}$} \\
\hline $\mathrm{DM}(\%)$ & 45.5 & 45.2 & 45.4 & 1.0 \\
\hline $\mathrm{CP}(\%$ of $\mathrm{DM})$ & 16.4 & 16.8 & 16.3 & 0.4 \\
\hline Ether extract (\% of DM) & $5.7^{\mathrm{a}}$ & $6.0^{\mathrm{a}}$ & $4.1^{\mathrm{b}}$ & 0.2 \\
\hline NDF (\% of DM) & $36.6^{\mathrm{a}}$ & $36.5^{\mathrm{a}}$ & $29.9^{\mathrm{b}}$ & 0.9 \\
\hline $\mathrm{ADF}(\%$ of $\mathrm{DM})$ & 21.4 & 21.5 & 19.6 & 0.6 \\
\hline $\mathrm{NFC}^{5}(\%$ of $\mathrm{DM})$ & 34.6 & 34.0 & 47.6 & \\
\hline $\mathrm{NE}_{\mathrm{L}}^{5}(\mathrm{MJ} / \mathrm{kg})$ & 7.11 & 7.11 & 7.11 & \\
\hline \multicolumn{5}{|l|}{ Fatty acids (\% of total) } \\
\hline $14: 0$ & 0.16 & 0.18 & 0.75 & \\
\hline $16: 0$ & 10.76 & 10.83 & 30.03 & \\
\hline cis-9 16:1 & 0.17 & 0.15 & 0.26 & \\
\hline 18:0 & 2.87 & 2.90 & 3.18 & \\
\hline cis-9 18:1 & 18.96 & 17.44 & 26.63 & \\
\hline cis-11 18:1 & 0.80 & 0.67 & 0.86 & \\
\hline cis-9,cis-12 18:2 & 29.89 & 59.61 & 29.74 & \\
\hline cis-9, cis-12, cis-15 18:3 & 36.04 & 7.88 & 8.08 & \\
\hline $20: 0$ & 0.35 & 0.34 & 0.47 & \\
\hline
\end{tabular}

$\overline{\mathrm{a}, \mathrm{b}}$ Means within rows with different superscripts differ $(P<0.05)$.

${ }^{1}$ Megalac (MEG), Church and Dwight Co. Inc., Princeton, NJ

${ }^{2}$ Contained $20 \%$ of canola meal, $30 \%$ of corn gluten meal, $20 \%$ of soybean meal and $30 \%$ of brewer's corn.

${ }^{3}$ Contained $9.2 \% \mathrm{Ca} ; 4.79 \% \mathrm{P} ; 4.78 \% \mathrm{Mg} ; 1.52 \% \mathrm{~S} ; 13.72 \% \mathrm{Na} ; 1.37 \% \mathrm{~K} ; 19.5 \mathrm{mg} / \mathrm{kg}$ of Se; $23 \mathrm{mg} / \mathrm{kg}$ of I; $2,013 \mathrm{mg} / \mathrm{kg}$ of Fe; $1,068 \mathrm{mg} / \mathrm{kg}$ of Cu; $1,796 \mathrm{mg} / \mathrm{kg}$ of Mn; 2,657 mg/kg of Zn; $57 \mathrm{mg} / \mathrm{kg}$ of Co; $265 \mathrm{mg} / \mathrm{kg}$ of $\mathrm{F} ; 442,000 \mathrm{UI} / \mathrm{kg}$ of vitamin A; 56,670 UI $/ \mathrm{kg}$ of vitamin of D; and 2,630 UI $/ \mathrm{kg}$ of vitamin $\mathrm{E}$.

${ }^{4}$ Mean of 6 weekly samples prepared by compositing weekly samples.

${ }^{5}$ Calculated using published values (NRC, 2001). 
standards (Larodan Fine Chemicals, Solna, Sweden; Sigma-Aldrich, St. Louis, MO; Matreya LLC, Pleasant Gap, PA; Nu-Chek Prep, Elysian, MN; Naturia, Sherbrooke, QC, Canada). Standards for trans-5 18:1 and trans-16 18:1 were not available commercially and were identified by order of elution according to the method of Precht et al. (2001). The response factor for cis-9 18:1 was used to quantify these trans 18:1 isomers.

Plasma samples were analyzed for concentrations of fatty acids by oxidation of CoA esters to hydrogen peroxide and further oxidative condensation using peroxidase (NEFA C-kit, Wako Chemicals USA, Richmond, VA), as described by McCutcheon and Bauman (1986); glucose by the glucose oxidase method (Genzyme Glucose, BioPacific Diagnostic Inc., BC, Canada), as described by Trinder (1969); and BHB based on oxidation of BHB to acetone by acetoacetate decarboxylase (Pointe Scientific, Canton, MI,) according to Williamson et al. (1962).

Samples of frozen liver $(80 \mathrm{mg})$ were homogenized in PBS. Liver samples were analyzed for glycogen using a colorimetric method (Sekisui Glucose-SL, BioPacific Diagnostic Inc., BC, Canada) according to the modified procedure of Andersen et al. (2002). Lipids were extracted from liver samples by the method of Folch et al. (1957) and triacylglycerol content was measured following saponification of glycerides and oxidation into formaldehyde according to the procedure of Fletcher (1968) as modified by Foster and Dunn (1973). Liver antioxidant activities were analyzed for SOD by reaction with xanthine oxidase and dismutation of superoxide radical (kit 706002, Cayman Chemical, Ann Arbor, MI); CAT by formation of formaldehyde by reaction with methanol (kit 707002, Cayman Chemical); and glutathione peroxidase (GPX) by a coupled reaction with glutathione reductase and formation of $\mathrm{NADP}^{+}$ (kit 703102, Cayman Chemical).

\section{Statistical Analysis}

Measurements of DMI and milk yield were reduced to weekly means before statistical analysis. The model included the fixed effects of treatment, week, treatment by week interaction and the residual error. Data on DMI were first analyzed separately for the prepartum and postpartum periods. Data on DMI were further analyzed as repeated measurements using PROC MIXED (SAS Institute, 2000), and the mean prepartum DMI was included in the analysis due to the lack of a treatment effect in the prepartum period. Milk production, milk composition, and plasma and hepatic parameters were also analyzed as repeated measurements. The following covariance structures were used based upon the smallest Akaike's information criterion values: CS for $\mathrm{kg} / \mathrm{d}$ of $\mathrm{TS}, \mathrm{kg} / \mathrm{d}$ of protein and $\mathrm{kg} / \mathrm{d}$ of fat; $\mathrm{AR}(1)$ for $\mathrm{kg} / \mathrm{d}$ of lactose and \% of lactose; $\mathrm{ARH}(1)$ for $\%$ of protein, and \% of TS; and ANTE(1) for \% of fat and $\log$ SCS. When differences $(P<0.10)$ due to dietary treatments were detected, treatment sums of squares were partitioned to provide contrasts and compared: (1) WFL versus WLO and (2) PUFA versus MEG. Differential temporal responses to dietary treatments were further examined using the SLICE option of the MIXED procedure. Significance was declared at $P \leq$ 0.05 and a trend at $0.05<P \leq 0.10$ unless otherwise stated. Residuals were plotted to detect assumptions of normality and homogeneity of variance. Data on SCC were transformed $(\log )$ because of a lack of variance homogeneity.

\section{RESULTS AND DISCUSSION}

\section{Nutrient Composition of the Experimental Diets}

As expected, ether extract concentration was higher for WFL and WLO compared with MEG in both prepartum (Table 1) and postpartum (Table 2) TMR, but we found no difference between WFL and WLO. Calcium salts of palm oil represented $2.6 \%$ of the postpartum diet, which agrees with the manufacturer's recommendation of 1 to $2 \%$ of the DMI. The NDF content was lower in MEG than in WFL and WLO in the postpartum diets, but it was similar for WFL and WLO. In both prepartum and postpartum diets, the main fatty acids were cis-9, cis-12, cis-15 18:3 (n-3 fatty acids) and cis-9,cis-12 18:2 (n-6 fatty acids) for WFL, cis-9,cis-12 18:2 for WLO, and cis-9,cis-12 18:2, 16:0, and cis-9 18:1 for MEG. Compared with whole flaxseed, whole linola had greater ether extract (44.9 vs. $40.8 \%$ DM, respectively) and NDF (21.0 vs. $17.8 \%$ DM, respectively) contents (Table 3). The main fatty acid present in whole flaxseed was cis-9, cis-12, cis-15 18:3 (54.94\%), whereas it was cis-9, cis-12 18:2 in whole linola $(72.77 \%)$.

\section{Feed Intake, BW, BCS, and Energy Balance}

Although ether extract concentration was greater in WFL and WLO than in MEG $(6.2,6.5$, and 3.1\%, respectively), prepartum DMI was similar among treatments $(12.0,11.1$, and $12.4 \mathrm{~kg} / \mathrm{d}$, respectively). We noted no interaction between treatment and week for BW and BCS, and treatment had no effect (Table 4). This agrees with the results of Hayirli and Grummer (2004), who reported that increasing dietary ether extract concentration up to $5.7 \%$ has no effect on prepartum DMI of multiparous cows. Moreover, similar prepartum DMI has been reported for cows fed for ad libitum intake di- 
Table 3. Chemical and fatty acid composition of whole flaxseed and whole linola

\begin{tabular}{|c|c|c|}
\hline Item & $\begin{array}{l}\text { Whole } \\
\text { flaxseed }\end{array}$ & $\begin{array}{l}\text { Whole } \\
\text { linola }\end{array}$ \\
\hline \multicolumn{3}{|l|}{ Chemical analysis $^{1}$} \\
\hline $\mathrm{DM}(\%)$ & 95.4 & 95.7 \\
\hline $\mathrm{CP}(\%$ of $\mathrm{DM})$ & 23.7 & 21.9 \\
\hline Ether extract ( $\%$ of DM) & 40.8 & 44.9 \\
\hline $\mathrm{NDF}(\%$ of DM) & 17.8 & 21.0 \\
\hline $\mathrm{ADF}(\%$ of $\mathrm{DM})$ & 10.4 & 9.8 \\
\hline \multicolumn{3}{|l|}{ Fatty acids ( $\%$ of total) } \\
\hline $14: 0$ & 0.04 & 0.05 \\
\hline $16: 0$ & 5.22 & 5.29 \\
\hline cis-9 16:1 & 0.05 & 0.04 \\
\hline 18:0 & 3.39 & 3.40 \\
\hline cis-9 18:1 & 19.15 & 16.05 \\
\hline cis-11 18:1 & 0.78 & 0.63 \\
\hline cis-9,cis-12 18:2 & 16.30 & 72.77 \\
\hline cis-9,cis-12,cis-15 18:3 & 54.94 & 1.66 \\
\hline $20: 0$ & 0.13 & 0.11 \\
\hline
\end{tabular}

${ }^{1}$ Mean of 6 weekly samples prepared by compositing weekly samples during the precalving period and mean of 4 weekly samples prepared by compositing weekly samples during the postcalving period.

ets supplemented with liquid fat (Douglas et al., 2004) or containing $5.9 \%$ whole flaxseed or $2.7 \%$ calcium salts of palm oil (Petit and Benchaar, 2007).

Likewise, we found no differences in postpartum DMI, BW, and BCS. However, when average DMI for the prepartum period was included in the analysis, we noted a trend for an interaction between treatment and week for DMI (expressed in $\mathrm{kg} / \mathrm{d} ; P=0.08$; Figure 1) and a significant effect of treatment and week for DM (expressed as \% of BW; $P=0.01$; Figure 2). There was a difference $(P=0.04)$ between PUFA and MEG for DMI (expressed as \% of BW), and cows fed PUFA increased DMI over time at a greater extent than those fed MEG. Petit and Benchaar (2007) have previously reported that feeding a diet with whole flaxseed increased postpartum DMI on different weeks. Evidence exists that lipids supplied as whole oilseeds have less negative effects on ruminal function compared with sources readily available due to slower release of fat in the rumen (Martin et al., 2008). Indeed, when diets with similar ether extract concentrations were fed to dairy cows, greater DMI was obtained with whole flaxseed than with extruded flaxseed or flax oil (Chilliard et al., 2009). Furthermore, increasing concentrations of fatty acids from 2.6 to $7.1 \%$ of the DM incorporated as whole flaxseed (from 0 to $13.9 \%$ of the diet DM) resulted in similar DMI (Petit, 2015).

We observed an interaction $(P=0.04)$ between treatment and week for the energy balance, resulting in better energy balance for cows fed PUFA than for those fed MEG over time, especially from wk 10 to 14 (Figure 3). Energy balance was similar between cows fed WFL and WLO. Cows fed MEG were on negative energy

Table 4. Feed intake, BW, BCS, milk production and composition and energy balance of Holstein cows fed a TMR containing a source of n-3 fatty acids supplied as whole flaxseed (WFL), n-6 fatty acids supplied as whole linola (WLO), or calcium salts of palm oil (MEG ${ }^{1}$ )

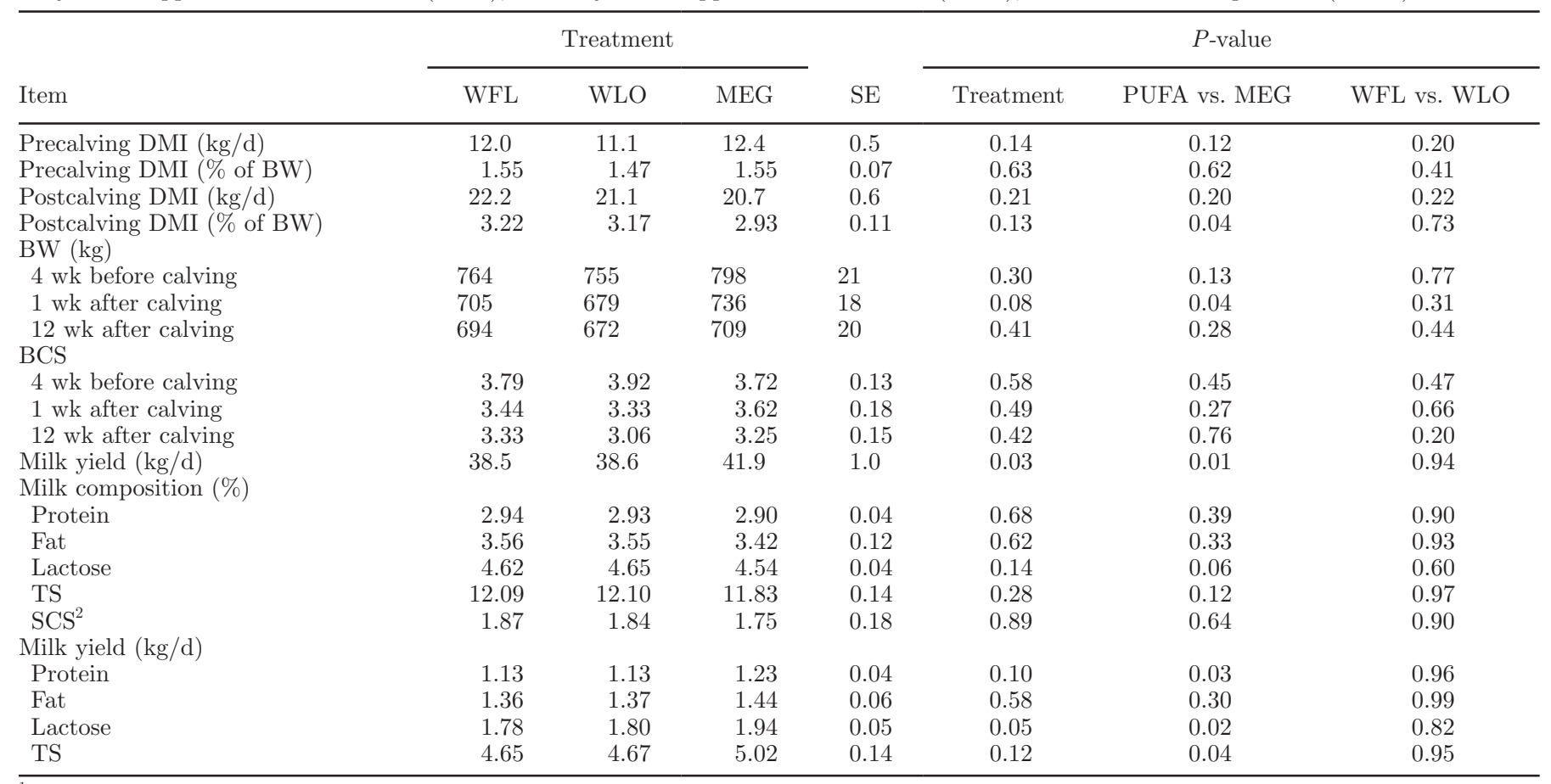

${ }^{1}$ Megalac, Church and Dwight Co. Inc., Princeton, NJ.

${ }^{2}$ Somatic cell score $=\log _{10}$ SCS. 


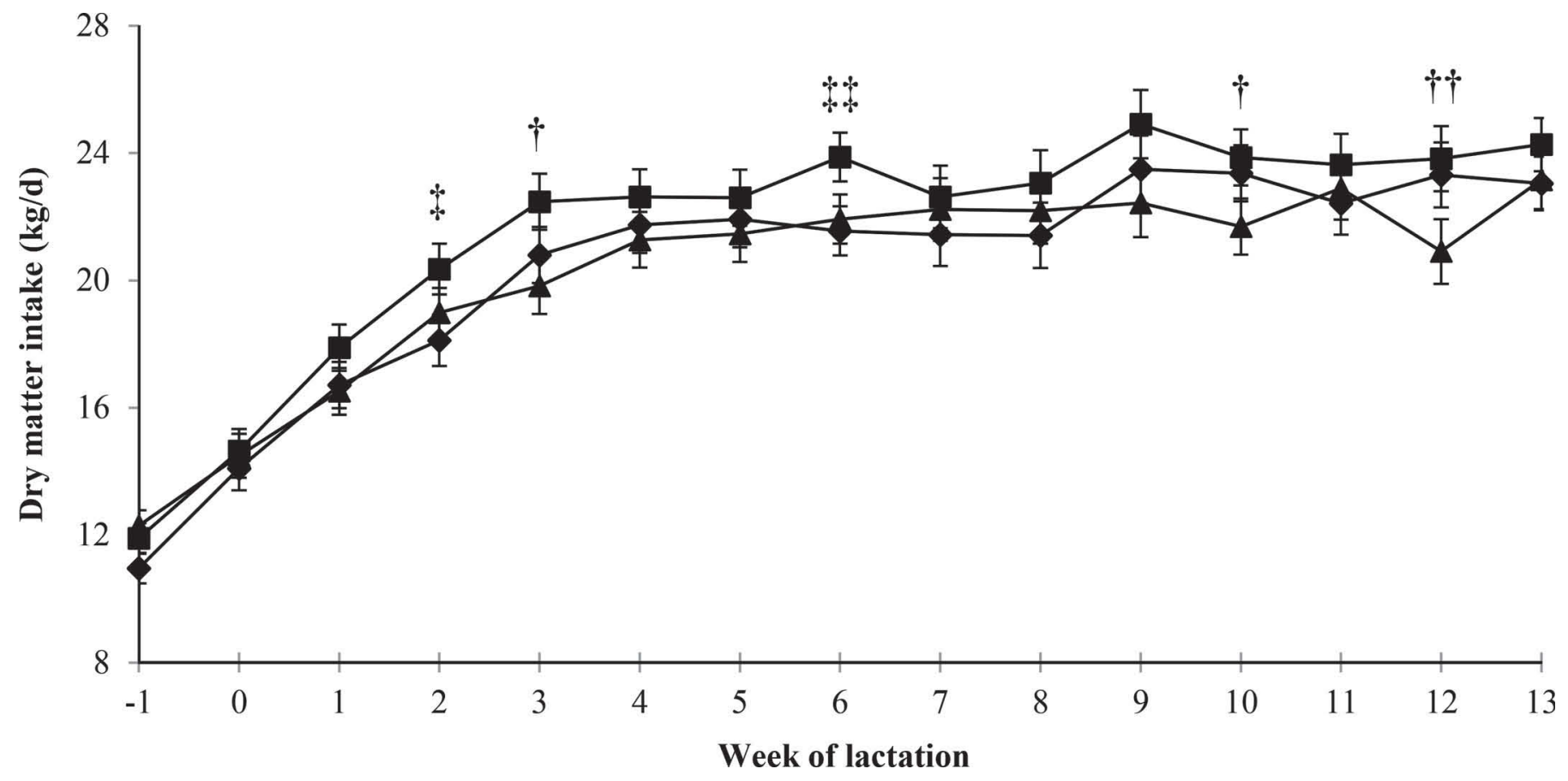

Figure 1. Dry matter intake of lactating dairy cows fed whole flaxseed (WFL; $\mathbf{0}$ ), whole linola (WLO; $\bullet$ ) and calcium salts of palm oil [Megalac (MEG), Church and Dwight Co. Inc., Princeton, NJ; $\mathbf{\Delta}$. Probabilities of significance were 0.20 and 0.22 for effects of PUFA versus MEG and WLO versus WLO, respectively $(\mathrm{SE}=0.61)$. Significant effects of PUFA versus MEG $(P \leq 0.05)$, a trend of PUFA versus MEG $(0.05$ $<P \leq 0.10)$, significant effects of WFL versus WLO $(P \leq 0.05)$, and a trend of WFL versus WLO $(0.05<P \leq 0.10)$ at specific sampling times are denoted by $\dagger \dagger, \dagger, \ddagger \dagger$, and $\ddagger$, respectively. Error bars indicate SEM.

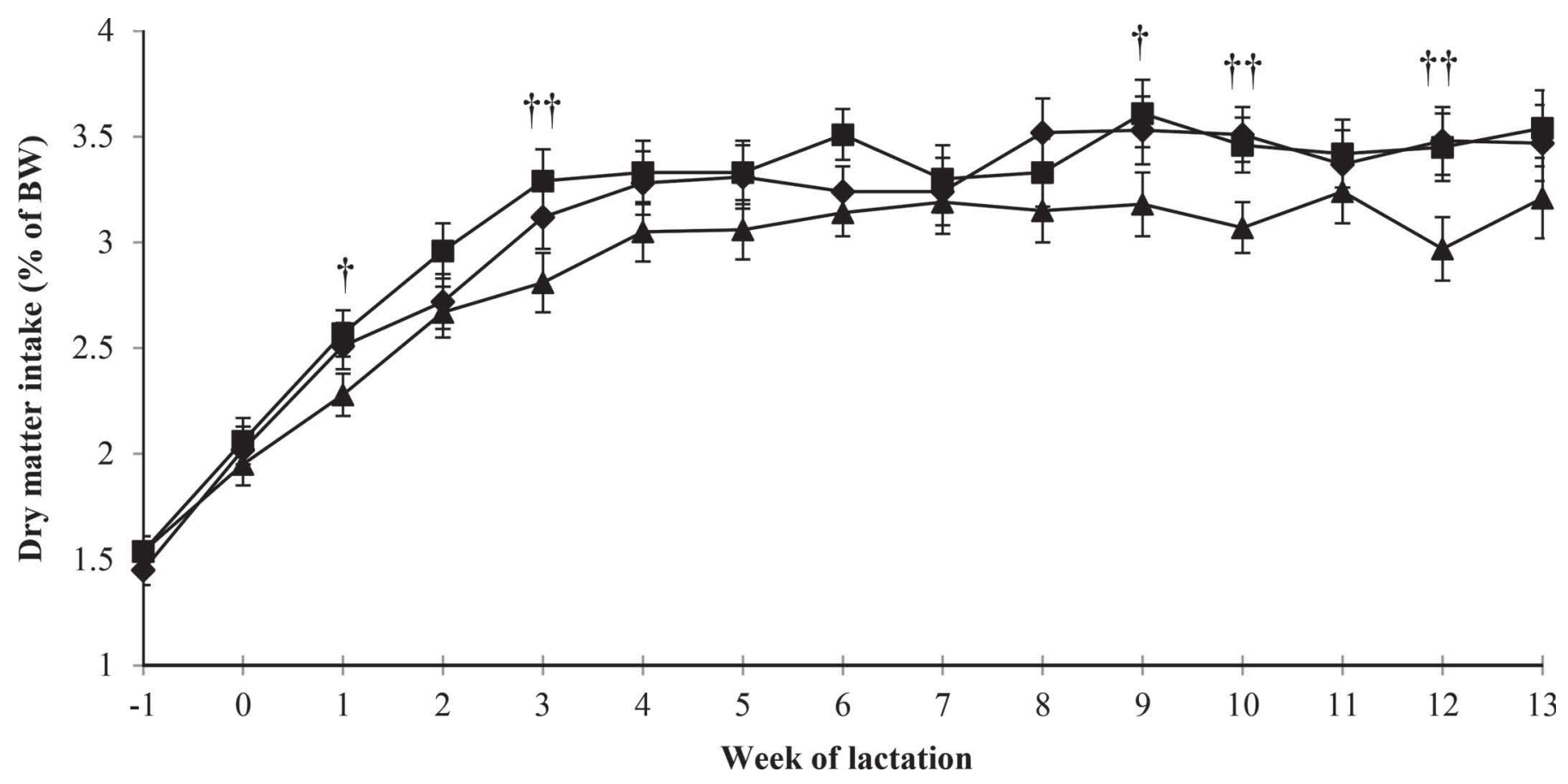

Figure 2. Dry matter intake as a percent of BW of lactating dairy cows fed whole flaxseed (WFL; $\mathbf{\square}$ ), whole linola (WLO; $\bullet$ ) and calcium salts of palm oil [Megalac (MEG), Church and Dwight Co. Inc., Princeton, NJ; $\mathbf{\Delta}$. Probabilities of significance were 0.05 and 0.73 for effects of PUFA versus MEG and WLO versus WLO, respectively $(\mathrm{SE}=0.11)$. Significant effects of PUFA versus MEG $(P \leq 0.05)$ and a trend of PUFA versus MEG $(0.05<P \leq 0.10)$ at specific sampling times are denoted by $\dagger \dagger$ and $\dagger$, respectively. Error bars indicate SEM. 


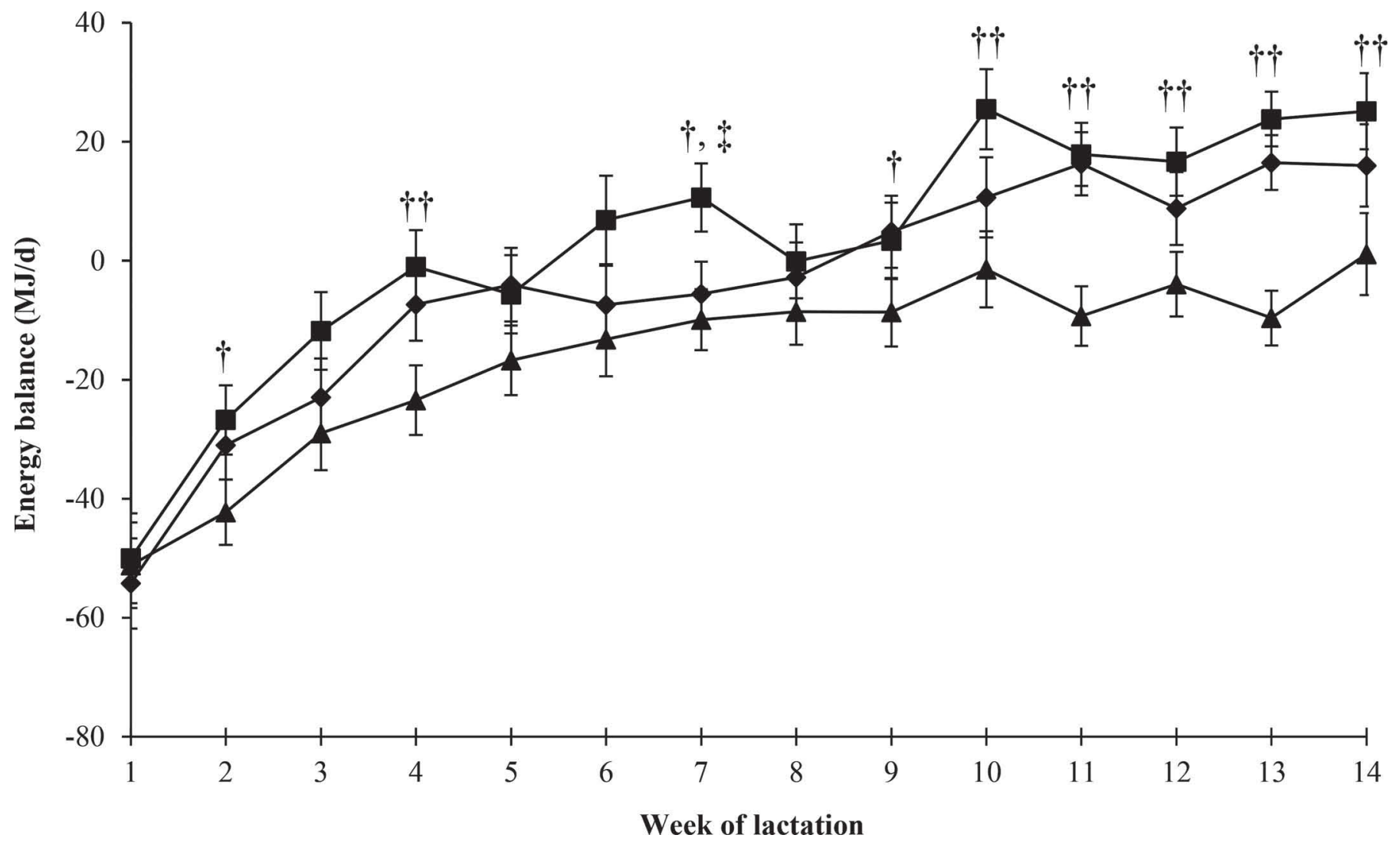

Figure 3. Energy balance of lactating dairy cows fed whole flaxseed (WFL; $\mathbf{0}$ ), whole linola (WLO; $\bullet$ ) and calcium salts of palm oil [Megalac (MEG), Church and Dwight Co. Inc., Princeton, NJ; $\mathbf{\Delta}$. Probabilities of significance were 0.007 and 0.25 for effects of PUFA versus MEG and WFL versus WLO, respectively $(\mathrm{SE}=1.05)$. Significant effects of PUFA versus MEG $(P \leq 0.05)$, a trend of PUFA versus MEG $(0.05<P$ $\leq 0.10)$, and a trend of WFL versus WLO $(0.05<P \leq 0.10)$ at specific sampling times are denoted by $\dagger \dagger$, $\dagger$, and $\ddagger$, respectively. Error bars indicate SEM.

balance until wk 14 of the postpartum period. Negative energy balance may result in higher incidence of metabolic and locomotion disorders as reported for cows experiencing short- or long-term negative energy balance (Grummer, 1993; Collard et al., 2000). The higher postpartum DMI for cows fed PUFA contributed to a more positive energy balance over time as previously observed for cows fed whole flaxseed (Petit et al., 2007) and extruded flaxseed (Zachut et al., 2010). However, as lipid content was lower in the diet of cows fed MEG than in the diet of those fed PUFA, one can presume that there was a confounding effect of diet composition (e.g., ether extract and NFC concentrations) on DMI and energy balance.

\section{Effect of Fat Sources on Milk Production and Composition}

Treatment affected $(P=0.03)$ milk yield averaged for the first $14 \mathrm{wk}$ of lactation (Table 4; Figure 4), with cows fed MEG producing more milk than those fed PUFA $(P=0.01)$. We found no difference in milk yield between cows fed WFL and WLO (Table 4). Despite the positive effects of feeding PUFA on DMI and energy balance, milk yield was higher for cows fed MEG, which disagrees with the results of Petit and Benchaar (2007), who found no difference in milk yield when cows were supplemented with whole flaxseed (11.4\%), calcium salts of palm oil $(5.1 \%)$, or micronized soybean $(14.7 \%)$ after calving. Similar milk yield and DMI were also reported by Petit and Côrtes (2010) when cows that averaged $30.5 \mathrm{~kg} / \mathrm{d}$ of milk were supplemented with $7.2 \%$ of whole flaxseed or $2.1 \%$ calcium salts of palm oil from calving to wk 28 of lactation. Conversely, Petit (2002) found higher milk yield for cows fed whole flaxseed $(10.4 \%)$ compared with those fed a source of calcium salts of palm oil (3.8\%). Discrepancies between experiments may result from differences in ingredient and chemical composition of diets. For example, in the present study, concentration of NDF was significantly 


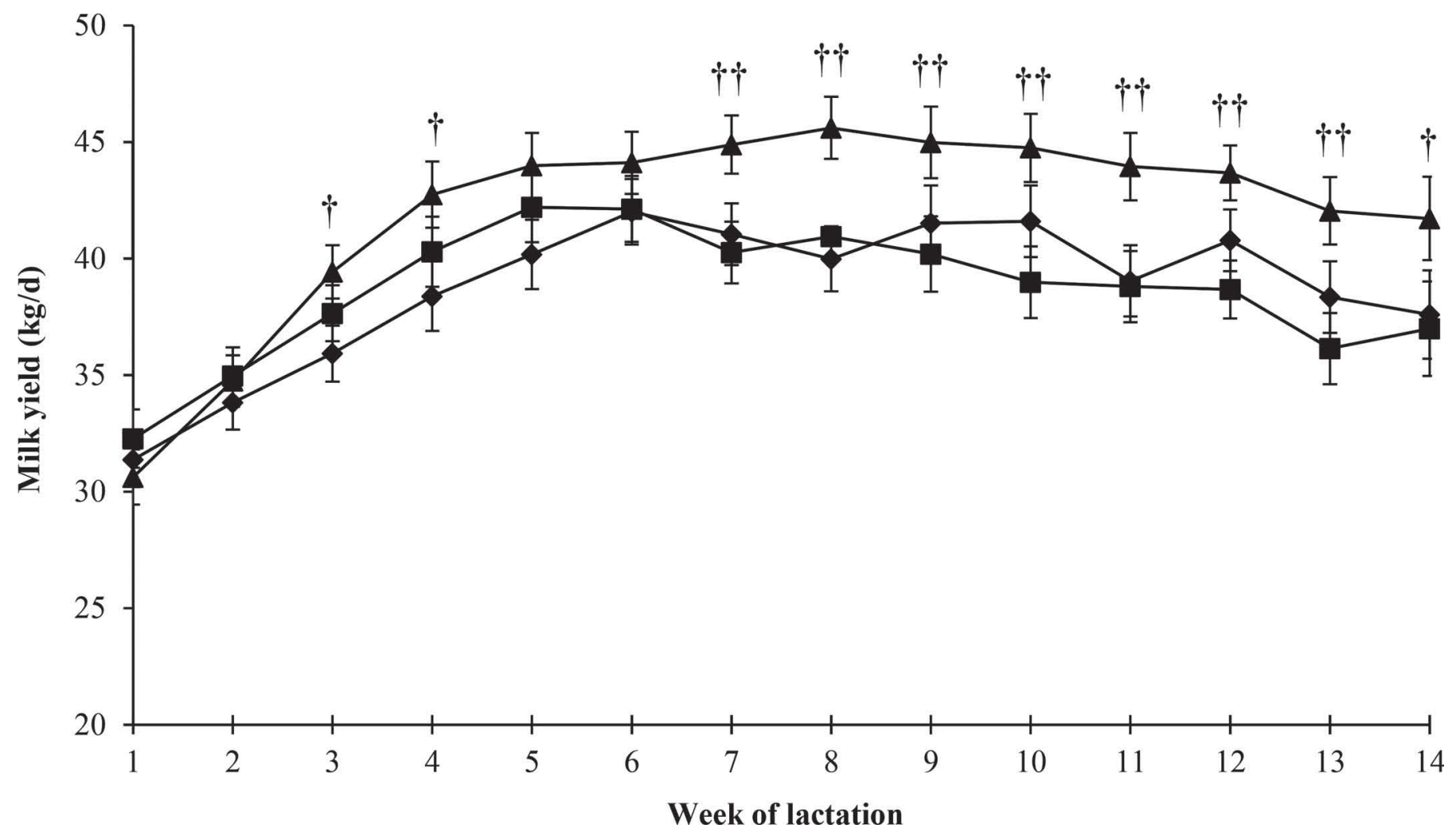

Figure 4. Milk yield of lactating dairy cows fed whole flaxseed (WFL; $\mathbf{0})$, whole linola (WLO; $\bullet$ ) and calcium salts of palm oil [Megalac (MEG), Church and Dwight Co. Inc., Princeton, NJ; $\mathbf{\Delta}$. Probabilities of significance were 0.01 and 0.93 for effects of PUFA versus MEG and WFLO versus WLO, respectively $(\mathrm{SE}=1.03)$. Significant effect of PUFA versus MEG $(P \leq 0.05)$, and a trend of PUFA versus MEG $(0.05<$ $P \leq 0.10)$, at specific sampling times are denoted by $\dagger \dagger$ and $\dagger$, respectively. Error bars indicate SEM.

lower for MEG than WFL and WLO, whereas NDF concentrations were similar among treatments in the experiment of Petit and Benchaar (2007). Lower dietary NDF concentration could have contributed to increased digestibility of the diet, thus resulting in a trend for enhanced milk yield for cows fed MEG in the present experiment. Moreover, a higher proportion of ether extract in the diet containing whole flaxseed than in that with calcium salts of palm oil may have contributed to increase milk yield for cows fed the former diet in the study of Petit (2002). Therefore, one can presume that there was a confounding effect of diet composition (e.g., NFC and ether extract concentrations) on milk yield.

We observed no effect on milk proportions of protein, fat, lactose, and TS and yield of fat (Table 4). Yields of protein, lactose, and TS were higher for cows fed MEG than for those fed PUFA. Milk fat yield and SCS were similar among diets. The lack of effect on proportions of milk protein, fat, lactose, and TS is in agreement with the results of Petit and Benchaar (2007). The higher yield of protein, lactose, and TS for cows fed MEG compared with those fed PUFA was likely a result of the higher milk production for cows fed the former diet.

\section{Effect of Fat Sources on Milk Fatty Acid Composition}

The proportion of C16:0 was higher for cows fed MEG than PUFA $(P<0.001)$ and we found a tendency between cows fed WFL and WLO (Table 5; $P=0.054$ ). Milk C16:0 is derived from the diet or synthesized in the mammary gland (Grummer, 1991). In the present experiment, higher intake of C16:0 was likely responsible for the higher content of $\mathrm{C} 16: 0$ in the milk of cows fed MEG, which is undesirable for human health due to its hypercholesterolemic effects (McGuire et al., 1997). The proportions of C10:0, C12:0, and C14:0 were higher in milk fat of cows fed WFL than in that of cows fed WLO. Feeding PUFA increased milk C18:0 compared with MEG. We noted a difference $(P=0.010)$ between cows fed WFL and WLO for the proportion of total trans 18:1. Milk cis-9,trans-11 18:2 was almost 2-fold higher for WLO compared with WFL $(P<0.001)$, and there was a tendency between cows fed PUFA and MEG $(P=0.061)$. This may result from desaturation of trans-11 C18:1 in the mammary gland or biohydrogenation of C18:2 by rumen microbes (Harfoot and Hazlewood, 1997). Intake of C18:2 was likely higher 
Table 5. Average milk fatty acid composition of Holstein cows fed a TMR containing a source of n-3 fatty acids supplied as whole flaxseed (WFL), n-6 fatty acids supplied as whole linola (WLO), or calcium salts of palm oil (MEG ${ }^{1}$ )

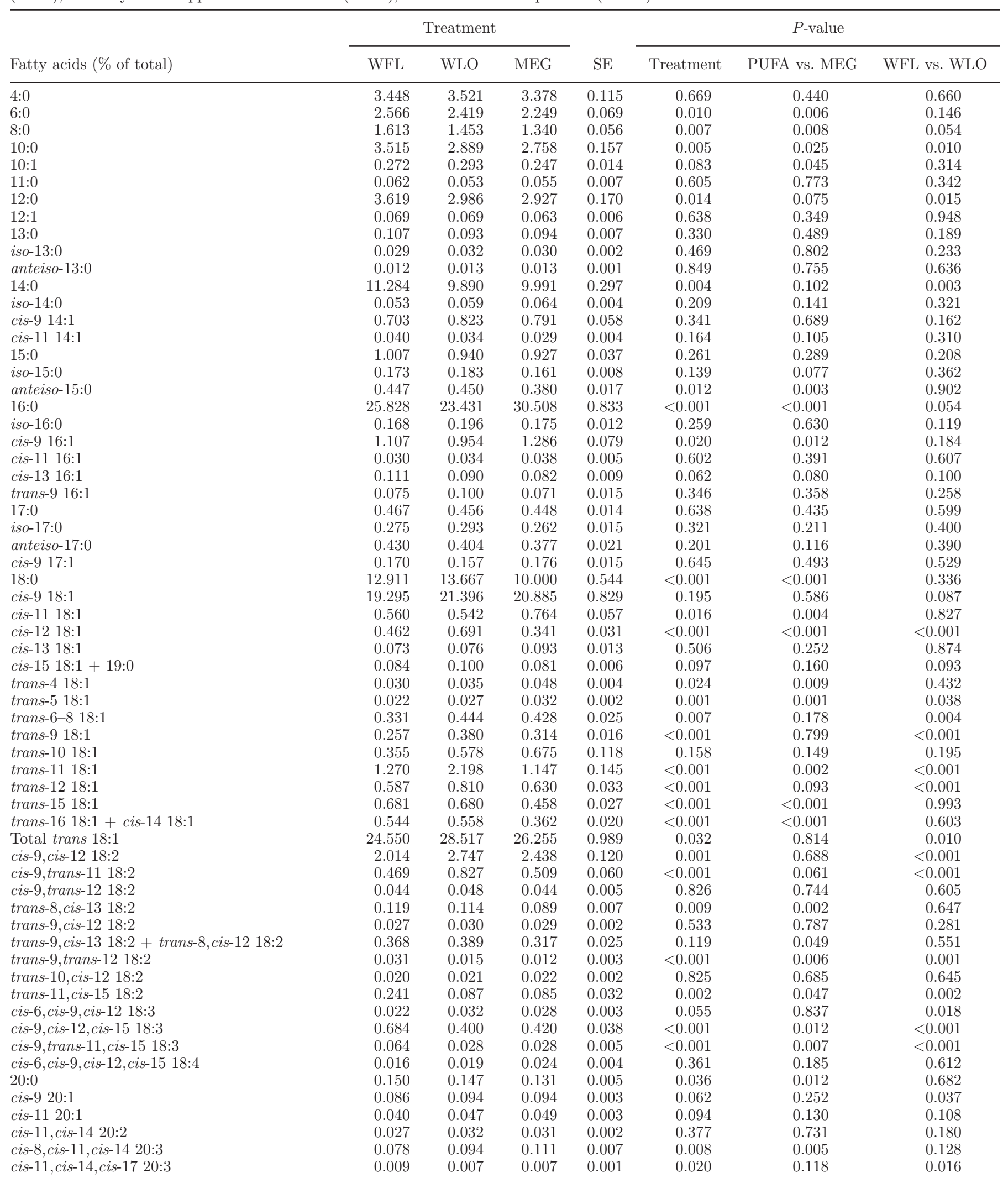


Table 5 (Continued). Average milk fatty acid composition of Holstein cows fed a TMR containing a source of n-3 fatty acids supplied as whole flaxseed (WFL), n-6 fatty acids supplied as whole linola (WLO), or calcium salts of palm oil (MEG ${ }^{1}$ )

\begin{tabular}{|c|c|c|c|c|c|c|c|}
\hline \multirow[b]{2}{*}{ Fatty acids (\% of total) } & \multicolumn{3}{|c|}{ Treatment } & \multirow[b]{2}{*}{$\mathrm{SE}$} & \multicolumn{3}{|c|}{$P$-value } \\
\hline & WFL & WLO & MEG & & Treatment & PUFA vs. MEG & WFL vs. WLO \\
\hline cis-8,cis-11,cis-14,cis-17 20:4 & 0.006 & 0.006 & 0.006 & 0.001 & 0.940 & 0.828 & 0.784 \\
\hline cis-5,cis-8,cis-11,cis-14,cis-17 20:5 & 0.057 & 0.035 & 0.037 & 0.002 & $<0.001$ & 0.002 & $<0.001$ \\
\hline $22: 0$ & 0.041 & 0.035 & 0.036 & 0.003 & 0.383 & 0.638 & 0.196 \\
\hline cis-13 22:1 & 0.006 & 0.007 & 0.007 & 0.000 & 0.138 & 0.616 & 0.056 \\
\hline cis-4,cis- 7, cis-10,cis-13,cis-16 22:5 & 0.011 & 0.009 & 0.011 & 0.001 & 0.308 & 0.598 & 0.152 \\
\hline cis- 7, cis-10,cis-13,cis-16,cis-19 22:5 & 0.070 & 0.049 & 0.059 & 0.004 & 0.001 & 0.814 & $<0.001$ \\
\hline cis-4,cis-7,cis-10,cis-13,cis-16,cis-19 22:6 & 0.009 & 0.008 & 0.009 & 0.001 & 0.922 & 0.964 & 0.693 \\
\hline $24: 0$ & 0.023 & 0.024 & 0.025 & 0.003 & 0.780 & 0.509 & 0.821 \\
\hline cis-9 24:0 & 0.008 & 0.009 & 0.010 & 0.001 & 0.666 & 0.385 & 0.838 \\
\hline
\end{tabular}

${ }^{1}$ Megalac, Church and Dwight Co. Inc., Princeton, NJ.

for cows fed WLO than for those fed the other diets as the proportion of C18:2 represented, respectively, 3.6, 1.7 , and $1.2 \%$ of the total DM for WLO, WFL, and MEG, thus increasing the amount of C18:2 available for ruminal biohydrogenation for cows fed the former diet. This is in agreement with the higher proportions of milk cis-9,trans-11 18:2 reported earlier by Ward et al. (2002) for dairy cows supplemented at $8.32 \%$ of DM with ground linola compared with those supplemented with ground flaxseed. As expected, milk cis-9, cis12,cis-15 18:3 was higher for cows fed WFL compared with WLO $(P<0.001)$ as flaxseed was the main source of cis-9,cis-12,cis-15 18:3, and was higher for PUFA compared with MEG $(P=0.012)$. The higher milk proportions of $\mathrm{C} 10: 0, \mathrm{C} 18: 0$, and cis-9,cis- 12, cis-15 18:3 for cows fed PUFA than for those fed MEG agree with the results of Petit (2002).

\section{Effect of Fat Sources on Plasma Parameters}

We found no difference in plasma concentrations of glucose (Figure 5a), fatty acids (Figure 5b), and BHB (Figure 5c) between PUFA and MEG and between WFL and WLO from wk 2 prepartum to wk 8 postpartum. A positive association was noted between DMI and plasma glucose concentration (Hayirli and Grummer, 2004), which was not observed in the present experiment. There was a week effect for plasma fatty acid concentrations as indicated by a 2 -fold increase from wk 2 to 1 before parturition and a 2 -fold increase from parturition to wk 1 after parturition, where values peaked before to decrease. Plasma BHB concentrations were stable before parturition but showed a 2 -fold increase from parturition to wk 1 postpartum. Differences in the energy balance among treatments were likely not important enough to affect plasma BHB concentrations.
These findings are in agreement with those of Petit and Benchaar (2007), who found no differences in plasma nonesterified fatty acid concentrations when dairy cows were fed whole flaxseed, calcium salts of palm oil or micronized soybean during the transition period. Zachut et al. (2010) also observed similar nonesterified fatty acid concentrations for cows fed extruded flaxseed and those fed a control diet.

\section{Effect of Fat Sources on Hepatic Parameters}

We observed no treatment effect on concentrations of glycogen, and activities of CAT, GPX, and SOD in the liver, but we noted a difference between cows fed PUFA and MEG for total lipids and triacylglycerol in the liver. Changes in glycogen concentration over time were similar among treatments (Figure 6a). All treatments resulted in liver lipid concentrations higher than values normally observed for cows. On average, hepatic triacylglycerol content on wh 2 postpartum was $7.3,7.3$, and $11.2 \%$ for cows fed WFL, WLO, and MEG, respectively, which is categorized as moderate and severe fatty liver, respectively (Bobe et al., 2004). The high content of liver lipids and triacylglycerol can be explained partly by the BCS that averaged 3.81 at beginning of the experiment. Indeed, cows with BCS higher than 4 are classified as being obese, and they have increased lipolysis at calving, decreased DMI, and severe negative energy balance (Stockdale, 2001) than normal cows. Greater lipolysis increases plasma concentration of fatty acids, which leads to increased fatty acids uptake by the liver and higher hepatic triacylglycerol concentration. Hepatic concentrations of lipids (Figure 6b) and triacylglycerol (Figure 6c) were higher and increased more over time for cows fed MEG than for those fed PUFA, and we found no difference 

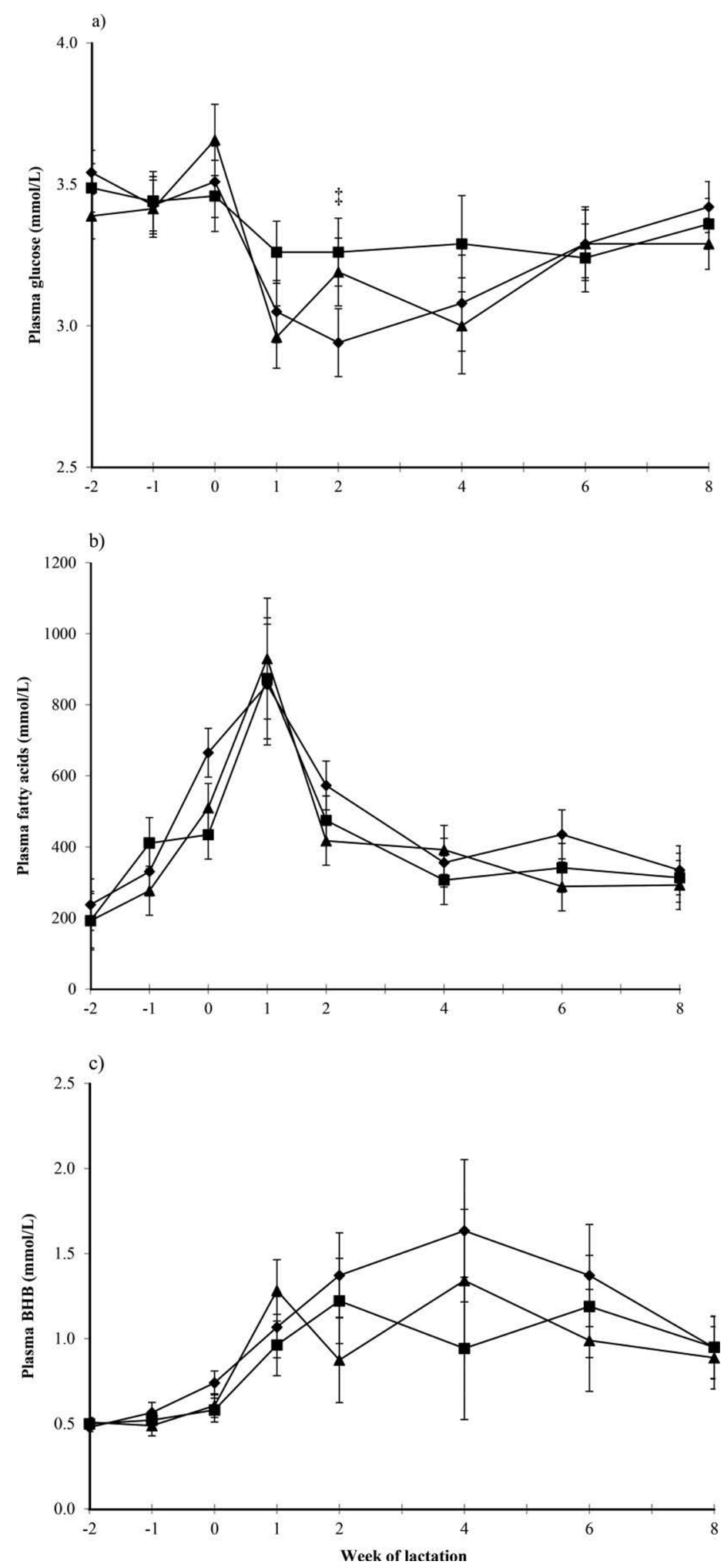

Figure 5. Plasma concentration of (a) glucose, (b) fatty acids, and (c) BHB of lactating dairy cows fed whole flaxseed (WFL; $\mathbf{a}$ ), whole linola (WLO; ) and calcium salts of palm oil [Megalac (MEG), Church and Dwight Co. Inc., Princeton, NJ; $\mathbf{\Delta}$. Probabilities of significance were 0.69 and 0.56 for effects of PUFA versus MEG and WFLO versus WLO, respectively $(\mathrm{SE}=0.08$; a). Probabilities of significance were 0.53 and 0.37 for effects of PUFA versus MEG and WFLO versus WLO, respectively ( $\mathrm{SE}=42.9$; b). Probabilities of significance were 0.64 and 0.33 for effects of PUFA versus MEG and WFLO versus WLO, respectively $(\mathrm{SE}=0.12$; c). A trend of WFL versus WLO $(0.05<P \leq 0.10)$ at specific sampling time is denoted by $\ddagger$. Error bars indicate SEM. 


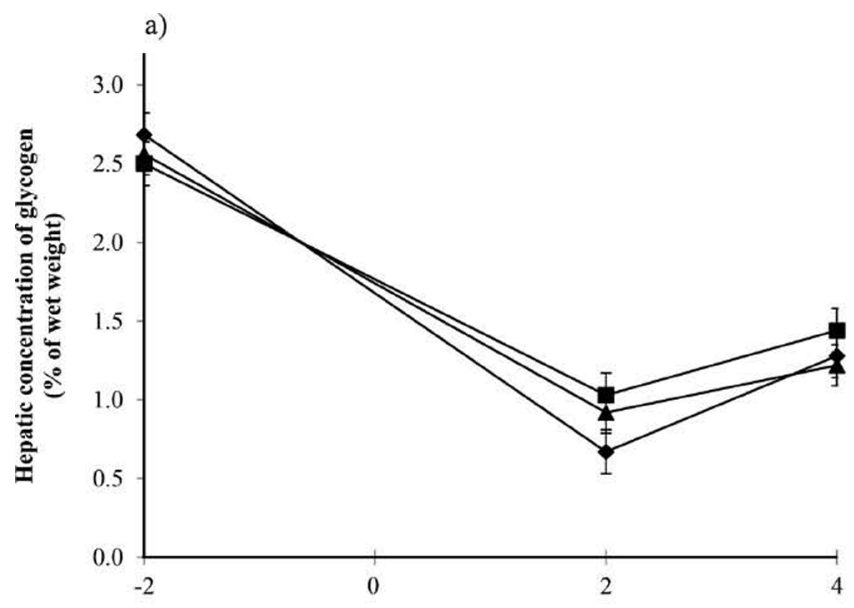

b)

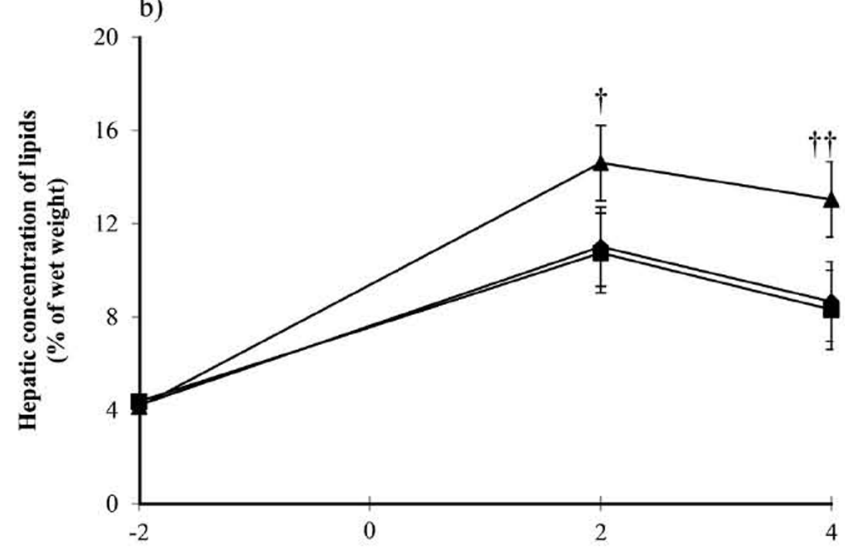

c)

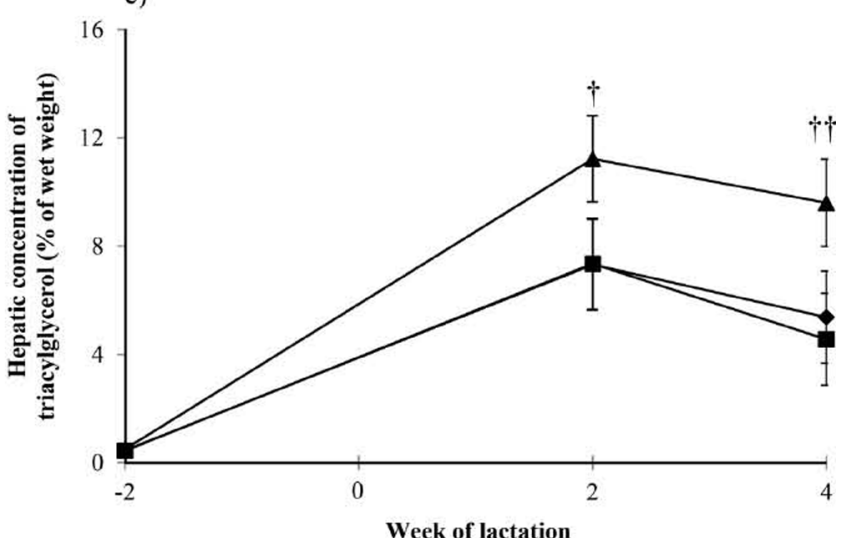

Figure 6. Liver concentration of (a) glycogen, (b) total lipids, and (c) triacylglycerol of lactating dairy cows fed whole flaxseed (WFL; -), whole linola (WLO; $\bullet$ ) and calcium salts of palm oil [Megalac (MEG), Church and Dwight Co. Inc., Princeton, NJ; $\mathbf{\Delta}$. Probabilities of significance were 0.88 and 0.61 for effects of PUFA versus MEG and WFLO versus WLO, respectively $(\mathrm{SE}=0.01$; a). Probabilities of significance were 0.03 and 0.91 for effects of PUFA versus MEG and WFLO versus WLO, respectively $(\mathrm{SE}=1.01 ; \mathrm{b})$. Probabilities of significance were 0.02 and 0.85 for effects of PUFA versus MEG and WFLO versus WLO, respectively $(\mathrm{SE}=0.97 ; \mathrm{c})$. Significant effects of PUFA versus MEG $(P \leq 0.05)$, and a trend of PUFA versus MEG $(0.05<P \leq 0.10)$, at specific sampling times are denoted by $\dagger \dagger$ and $\dagger$, respectively. Error bars indicate SEM. between WFL and WLO. Differences over time in hepatic triacylglycerol and lipids concentrations among diets may be explained by the metabolism of fatty acids depending on its profile. Indeed, a medium containing linoleic acid and linolenic acid decreases incorporation of fatty acids into cellular triacylglycerol of bovine hepatocytes almost by half compared with oleic acid and palmitic acid, suggesting a capacity for PUFA to decrease hepatic triacylglycerol accumulation (Mashek et al., 2002). However, although lower hepatic triacylglycerol concentration was observed when a source of n-3 fatty acids (fish oil) was fed to rodents compared with a source of n- 6 fatty acids (safflower oil) or a mixture of C16:0 and C18:1 (palm oil), no difference was observed between cows fed WFL and those fed WLO in the present experiment. Biohydrogenation of long-chain fatty acids by rumen microbes nullifies most differences in fatty acid profile (Grummer, 1991). However, cows fed PUFA had 26 and $35 \%$ less liver total lipids and triacylglycerol contents, respectively, than those fed MEG on wk 4 postpartum compared with wk 2. Petit et al. (2007) also observed lower liver total lipids and triacylglycerol for cows fed a diet with whole flaxseed compared with a diet with calcium salts of palm oil. Triacylglycerol hepatic accumulation is associated with aberrant function of the liver, decreased DMI, and lower reproductive performance of dairy cows (Bobe et al., 2004).

We noted a tendency for hepatic CAT activity (Figure 7a) to increase over time when cows were fed WFL $(5,003 \mathrm{U} / \mathrm{mg}$ of protein) compared with when they were fed WLO (4,147 U/mg of protein). Activities of GPX (Figure 7b) and SOD (Figure 7c) decreased after calving. The higher activities of hepatic SOD and GPX observed before calving are in agreement with the results obtained in red blood cells of dairy cows during the periparturient period (Stefanon et al., 2005). Moreover, a higher increase over time in CAT activity for cows fed WFL may suggest that a physiological response of the antioxidant defense system was partially involved to face an increased stress susceptibility, ensuring that potential oxidants are metabolized and promptly removed from the organism. Indeed, CAT is the enzyme involved in the second step of removing the peroxides produced by SOD and leading to oxidative stress, converting them into $\mathrm{H}_{2} \mathrm{O}$ and $\mathrm{O}_{2}(\mathrm{Yu}, 1994)$. Flaxseed oil upregulates activity and expression of CAT and SOD, and expression of GPX in induced diabetic rats (Jangale et al., 2013); thus, flaxseed could contribute to enhance protection of the body against stress occurring during the transition period. This agrees with the results of Rajesha et al., (2006) who found that flaxseed provided protection against stress induced by a toxin as shown by increase hepatic CAT activity, which 


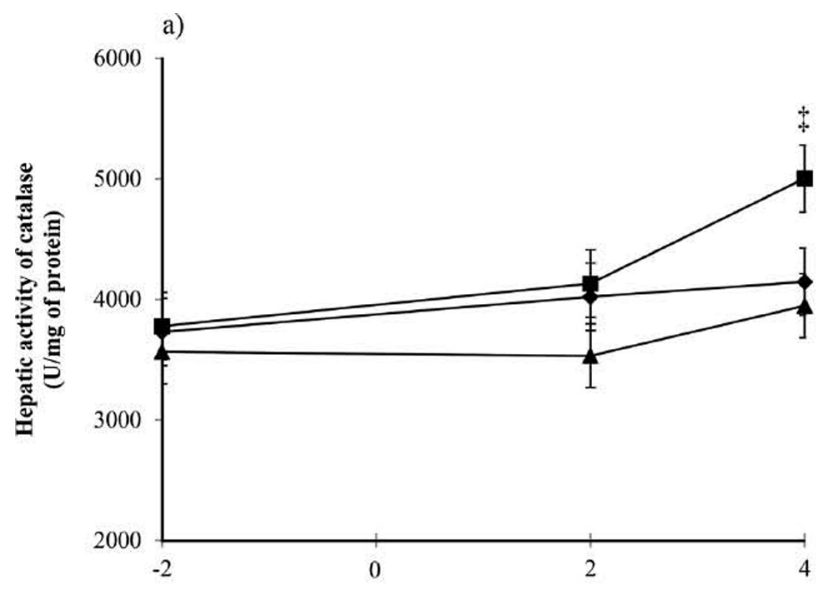

b)

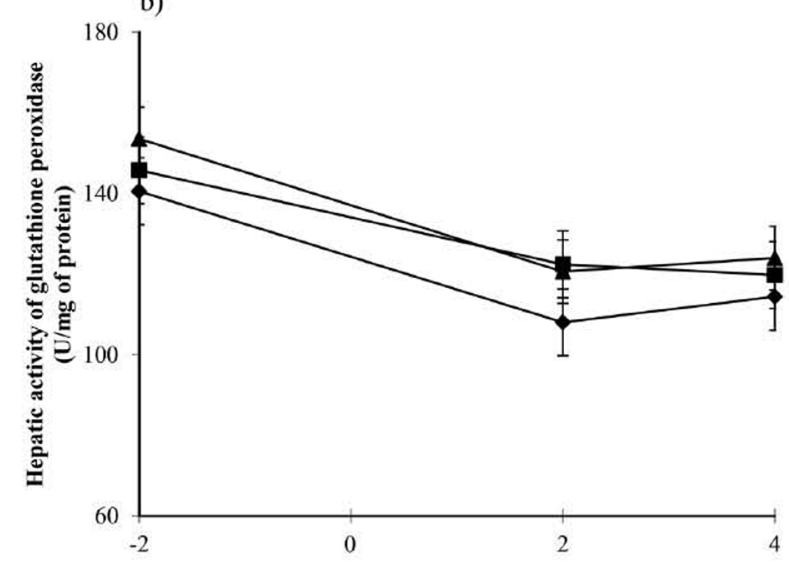

c)

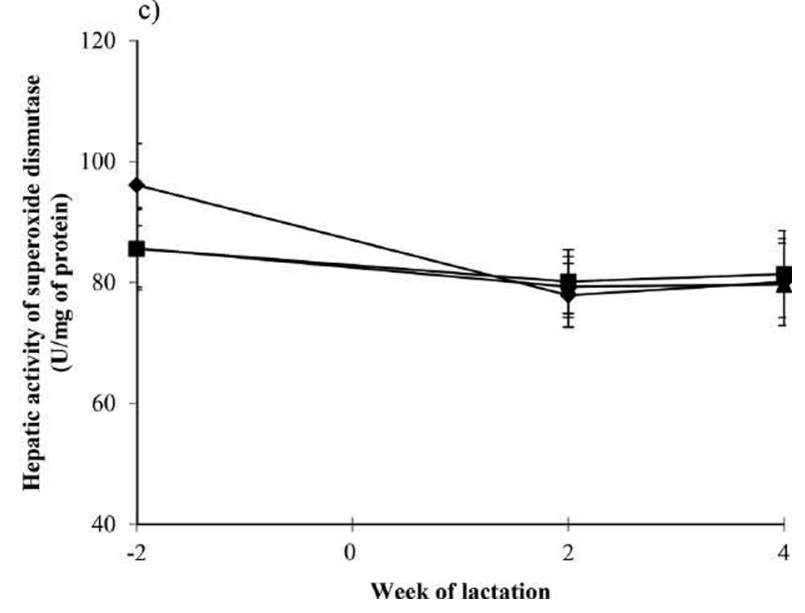

Figure 7. Hepatic activity of (a) catalase, (b) glutathione peroxidase, and (c) superoxide dismutase of lactating dairy cows fed whole flaxseed (WFL; ), whole linola (WLO; $\bullet$ ) and calcium salts of palm oil [Megalac (MEG), Church and Dwight Co. Inc., Princeton, NJ; $\mathbf{\Delta}$ ]. Probabilities of significance were 0.11 and 0.31 for effects of PUFA versus MEG and WFLO versus WLO, respectively $(\mathrm{SE}=232$; a). Probabilities of significance were 0.43 and 0.46 for effects of PUFA versus MEG and WFLO versus WLO, respectively $(\mathrm{SE}=7.94 ; \mathrm{b})$. Probabilities of significance were 0.76 and 0.76 for effects of PUFA versus MEG and WFLO versus WLO, respectively $(\mathrm{SE}=5.46$; $\mathrm{c}$ ). Trend of WFL versus WLO $(0.05<P \leq 0.10)$ at specific sampling times are denoted by $\ddagger$. Error bars indicate SEM. may likely attenuate health disorders. As the main difference between the WFL and WLO diets was in the higher proportion of $n-3$ in WFL and higher one of n-6 fatty acids in WLO, this suggests that n-3 fatty acids were responsible for the increase in CAT activity in cows fed the former diet. This corroborates our earlier findings, where it was reported that cows fed $9.88 \%$ flaxseed hulls ( $53.4 \%$ of total fatty acids as linolenic acid) have higher levels of CAT mRNA in mammary tissue than cows fed no flaxseed hulls and that the activity of CAT in the mammary gland is modulated by n-3 PUFA (Côrtes et al., 2012).

\section{CONCLUSIONS}

Cows fed sources of n-3 and n-6 fatty acids had a greater DMI over time compared with those fed calcium salts of palm oil, which resulted in enhanced energy balance. Milk yield was higher for cows fed calcium salts of palm oil than for those fed PUFA; however, as lipid content was lower and NFC concentration was higher in the diet of cows fed MEG than in the diet of those fed PUFA, one can presume that there was a confounding effect of diet composition (e.g., ether extract and NFC concentrations) on DMI and energy balance. Blood metabolites were similar among diets. Cows supplemented with whole linola and whole flaxseed had lower content of hepatic lipids and triacylglycerol and a greater decrease over time after calving compared with those fed calcium salts of palm oil, which may decrease susceptibility for metabolic diseases. Despite the difference in proportions of n-3 and n- 6 fatty acids between the flaxseed and linola based diets, the only tendency of treatment was for higher hepatic CAT activity over time after calving for cows supplemented with whole flaxseed. Although feeding linoleic and linolenic acids as unprotected oilseeds decreased milk production and had no effect on blood parameters compared with a source of calcium salts of palm oil, increased DMI over time to a greater extent for cows fed PUFA improved the energy status and lowered hepatic lipids and triacylglycerol contents, which may contribute to enhance the health status of transition dairy cows.

\section{ACKNOWLEDGMENTS}

The present study was funded by Dairy Farmers of Canada and Agriculture and Agri-Food Canada. The authors express their gratitude to the staff of the Sherbrooke Research and Development Centre for their contribution to the present study. Special thanks go to Steve Méthot for his help in statistical analyses. 


\section{REFERENCES}

Adlercreutz, H., and W. Mazur. 1997. Phyto-oestrogens and Western diseases. Ann. Med. 29:95-120.

Andersen, J. B., D. G. Mashek, T. Larsen, M. O. Nielsen, and K. L. Ingvartsen. 2002. Effects of hyperinsulinaemia under euglycaemic condition on liver fat metabolism in dairy cows in early and midlactation. J. Vet. Med. A Physiol. Pathol. Clin. Med. 49:65-71.

AOAC. 1990. Official Methods of Analysis. 15th ed. Assoc. Off. Anal. Chem., Washington, DC.

Ballou, M. A., R. C. Gomes, S. O. Juchem, and E. J. DePeters. 2009. Effects of dietary supplemental fish oil during the peripartum period on blood metabolites and hepatic fatty acid compositions and total triacylglycerol concentrations of multiparous Holstein cows. J. Dairy Sci. 92:657-669.

Bobe, G., J. W. Young, and D. C. Beitz. 2004. Invited review: Pathology, etiology, prevention, and treatment of fatty liver in dairy cows. J. Dairy Sci. 87:3105-3124.

Canadian Council on Animal Care (CCAC). 1993. Guide to the Care and Use of Experimental Animals. Vol. 1. E. D. Olfert, B. M. Cross, and A. A. McWilliam, ed. CCAC, Ottawa, Ontario, Canada.

Chilliard, Y., C. Martin, J. Rouel, and M. Doreau. 2009. Milk fatty acids in dairy cows fed whole crude linseed, extruded linseed, or linseed oil, and their relationship with methane output. J. Dairy Sci. 92:5199-5211.

Chouinard, P. Y., V. Girard, and G. J. Brisson. 1997. Performance and profiles of milk fatty acids of cows fed full fat, heat-treated soybeans using various processing methods. J. Dairy Sci. 80:334-342.

Collard, B. L., P. J. Boettcher, J. C. M. Dekkers, D. Petitclerc, and L. R. Schaeffer. 2000. Relationships between energy balance and health traits of dairy cattle in early lactation. J. Dairy Sci. 83:2683-2690.

Côrtes, C., D. C. da Silva-Kazama, R. Kazama, N. Gagnon, C. Benchaar, G. T. D. Santos, L. M. Zeoula, and H. V. Petit. 2010 Milk composition, milk fatty acid profile, digestion, and ruminal fermentation in dairy cows fed whole flaxseed and calcium salts of flaxseed oil. J. Dairy Sci. 93:3146-3157.

Côrtes, C., M. F. Palin, N. Gagnon, C. Benchaar, P. Lacasse, and H. V. Petit. 2012. Mammary gene expression and activity of antioxidant enzymes and concentration of the mammalian lignan enterolactone in milk and plasma of dairy cows fed flax lignans and infused with flax oil in the abomasum. Br. J. Nutr. 108:1390-1398.

Douglas, G. N., T. R. Overton, H. G. Bateman Ii, and J. K. Drackley. 2004. Peripartal metabolism and production of Holstein cows fed diets supplemented with fat during the dry period. J. Dairy Sci. $87: 4210-4220$.

Dribnenki, J. C. P., S. F. McEachern, A. G. Green, E. O. Kenaschuk, and K. Y. Rashid. 1999. Linola ${ }^{\mathrm{TM}}$ '1084' low-linolenic acid flax. Can. J. Plant Sci. 79:607-609.

Edmonson, A. J., I. J. Lean, L. D. Weaver, T. Farver, and G. Webster. 1989. A body condition scoring chart for Holstein dairy cows. J. Dairy Sci. 72:68-78.

Fletcher, M. J. 1968. A colorimetric method for estimating serum triglycerides. Clin. Chim. Acta 22:393-397.

Folch, J., M. Lees, and G. H. S. Stanley. 1957. A simple method for the isolation and purification of total lipides from animal tissues. J. Biol. Chem. 226:497-509.

Foster, L. B., and R. T. Dunn. 1973. Stable reagents for determination of serum triglycerides by a colorimetric Hantzsch condensation method. Clin. Chem. 19:338-340.

Grummer, R. R. 1991. Effect of feed on the composition of milk fat. J. Dairy Sci. 74:3244-3257.

Grummer, R. R. 1993. Etiology of lipid-related metabolic disorders in periparturient dairy cows. J. Dairy Sci. 76:3882-3896.

Grummer, R. R. 2008. Nutritional and management strategies for the prevention of fatty liver in dairy cattle. Vet. J. 176:10-20.

Grummer, R. R., and D. J. Carroll. 1991. Effects of dietary fat on metabolic disorders and reproductive performance of dairy cattle. J. Anim. Sci. 69:3838-3852.
Harfoot, C. G., and G. P. Hazlewood. 1997. Lipid metabolism in the rumen. Pages 382-426 in The Rumen Microbial Ecosystem. P. N. Hobson and C. S. Stewart, ed. Springer, Dordrecht, the Netherlands.

Hayirli, A., and R. R. Grummer. 2004. Factors affecting dry matter intake prepartum in relationship to etiology of peripartum lipid-related metabolic disorders: A review. Can. J. Anim. Sci. 84:337-347.

Hayirli, A., D. H. Keisler, L. Doepel, and H. Petit. 2011. Peripartum responses of dairy cows to prepartal feeding level and dietary fatty acid source. J. Dairy Sci. 94:917-930.

Jangale, N. M., P. P. Devarshi, A. A. Dubal, A. E. Ghule, S. J. Koppikar, S. L. Bodhankar, A. D. Chougale, M. J. Kulkarni, and A. M. Harsulkar. 2013. Dietary flaxseed oil and fish oil modulates expression of antioxidant and inflammatory genes with alleviation of protein glycation status and inflammation in liver of streptozotocin-nicotinamide induced diabetic rats. Food Chem. 141:187-195.

Janovick, N. A., Y. R. Boisclair, and J. K. Drackley. 2011. Prepartum dietary energy intake affects metabolism and health during the periparturient period in primiparous and multiparous Holstein cows. J. Dairy Sci. 94:1385-1400.

Kiso, Y. 2004. Antioxidative roles of sesamin, a functional lignan in sesame seed, and it's effect on lipid- and alcohol-metabolism in the liver: A DNA microarray study. Biofactors 21:191-196.

Martin, C., J. Rouel, J. P. Jouany, M. Doreau, and Y. Chilliard. 2008. Methane output and diet digestibility in response to feeding dairy cows crude linseed, extruded linseed, or linseed oil. J. Anim. Sci. 86:2642-2650.

Mashek, D. G., S. J. Bertics, and R. R. Grummer. 2002. Metabolic fate of long-chain unsaturated fatty acids and their effects on palmitic acid metabolism and gluconeogenesis in bovine hepatocytes. J. Dairy Sci. 85:2283-2289.

Mashek, D. G., S. J. Bertics, and R. R. Grummer. 2005. Effects of intravenous triacylglycerol emulsions on hepatic metabolism and blood metabolites in fasted dairy cows. J. Dairy Sci. 88:100-109.

McCutcheon, S. N., and D. E. Bauman. 1986. Effect of chronic growth hormone treatment on responses to epinephrine and thyrotropinreleasing hormone in lactating cows. J. Dairy Sci. 69:44-51.

McGuire, M. A., M. K. McGuire, and M. S. McGuire. 1997. Bovinic acid: The natural CLA. Pages 217-226 in Proc. Cornell Nutr. Conf. Feed Manuf., Rochester, NY. Cornell Univ., Ithaca, NY.

NRC. 2001. Nutrient Requirements of Dairy Cattle. 7th rev. ed. Nat. Acad. Press, Washington, DC.

Palin, M. F., C. Côrtes, C. Benchaar, P. Lacasse, and H. V. Petit. 2014. mRNA Expression of lipogenic enzymes in mammary tissue and fatty acid profile in milk of dairy cows fed flax hulls and infused with flax oil in the abomasum. Br. J. Nutr. 111:1011-1020.

Park, P. W., and R. E. Goins. 1994. In situ preparation of fatty acid methyl esters for analysis of fatty acid composition in foods. J. Food Sci. 59:1262-1266.

Petit, H. V. 2002. Digestion, milk production, milk composition, and blood composition of dairy cows fed whole flaxseed. J. Dairy Sci. 85:1482-1490.

Petit, H. V. 2010. Milk production and milk composition of dairy cows fed flaxseed: a review. Can. J. Anim. Sci. 90:115-127.

Petit, H. V. 2015. Milk production and composition, milk fatty acid profile, and blood composition of dairy cows fed different proportions of whole flaxseed in the first half of lactation. Anim. Feed Sci. Technol. 205:23-30.

Petit, H. V., and C. Benchaar. 2007. Milk production, milk composition, blood composition, and conception rate of transition dairy cows fed different profiles of fatty acids. Can. J. Anim. Sci. 87:591600

Petit, H. V., and C. Côrtes. 2010. Milk production and composition, milk fatty acid profile, and blood composition of dairy cows fed whole or ground flaxseed in the first half of lactation. Anim. Feed Sci. Technol. 158:36-43.

Petit, H. V., M. F. Palin, and L. Doepel. 2007. Hepatic lipid metabolism in transition dairy cows fed flaxseed. J. Dairy Sci. 90:47804792 . 
Precht, D., J. Molkentin, M. A. McGuire, M. K. McGuire, and R. Jensen. 2001. Overestimates of oleic and linoleic acid contents in materials containing trans fatty acids and analyzed with short packed gas chromatographic columns. Lipids 36:213-216.

Rajesha, J., K. N. C. Murthy, M. K. Kumar, B. Madhusudhan, and G. A. Ravishankar. 2006. Antioxidant potentials of flaxseed by in vivo model. J. Agric. Food Chem. 54:3794-3799.

SAS Institute. 2000. Release 8.02. SAS Institute Inc., Cary, NC.

Schogor, A. L. B., M. F. Palin, G. T. dos Santos, C. Benchaar, P. Lacasse, and H. V. Petit. 2013. Mammary gene expression and activity of antioxidant enzymes and oxidative indicators in the blood, milk, mammary tissue and ruminal fluid of dairy cows fed flax meal. Br. J. Nutr. 110:1743-1750.

Stefanon, B., S. Sgorlon, and G. Gabai. 2005. Usefulness of nutraceutics in controlling oxidative stress in dairy cows around parturition. Vet. Res. Commun. 29:387-390

Stockdale, C. R. 2001. Body condition at calving and the performance of dairy cows in early lactation under Australian conditions: a review. Aust. J. Exp. Agric. 41:823-839.

Trinder, P. 1969. Determination of glucose in blood using glucose oxidase with an alternative oxygen acceptor. Ann. Clin. Biochem. $6: 24-27$.
Van Soest, P. J., J. B. Robertson, and B. A. Lewis. 1991. Methods for dietary fiber, neutral detergent fiber, and nonstarch polysaccharides in relation to animal nutrition. J. Dairy Sci. 74:3583-3597.

Ward, A. T., K. M. Wittenberg, and R. Przybylski. 2002. Bovine milk fatty acid profiles produced by feeding diets containing solin, flax and canola. J. Dairy Sci. 85:1191-1196.

White, H. M., S. L. Koser, and S. S. Donkin. 2011. Differential regulation of bovine pyruvate carboxylase promoters by fatty acids and peroxisome proliferator-activated receptor- $\alpha$ agonist. J. Dairy Sci. 94:3428-3436

Williamson, D. H., J. Mellanby, and H. A. Krebs. 1962. Enzymic determination of $\mathrm{d}(-)-\beta$-hydroxybutyric acid and acetoacetic acid in blood. Biochem. J. 82:90-96.

$\mathrm{Yu}$, B. P. 1994. Cellular defenses against damage from reactive oxygen species. Physiol. Rev. 74:139-162.

Zachut, M., A. Arieli, H. Lehrer, L. Livshitz, S. Yakoby, and U. Moallem. 2010. Effects of increased supplementation of n-3 fatty acids to transition dairy cows on performance and fatty acid profile in plasma, adipose tissue, and milk fat. J. Dairy Sci. 93:5877-5889. 